\title{
Kitty Tsui
}

\section{Suzy Wong's Been Dead a Long Time}

a friend calls, says,

after an Unbound Feet performance

she cried,

seeing for the first time in forty years

her own face on stage,

her father's voice in my play.

hears for the first time

about experiences so close to her own.

she says she never

experienced any racism

growing up yellow in Walnut Creek.

but after the show

three men trailed her,

a woman alone,

walking down University Avenue.

hey, you Oriental pussycat,

c'mon over here, Suzy Wong.

when she picked up speed,

crossed the street,

they yelled,

wouldn't fuck you no way,

flat face,

slant eye.

a friend calls, says,

i'm real depressed,

even thought about suicide.

can't find a job, 
can't pay the rent, got a dollar in the bank and thirty cents in my pocket. even thought about posing for porno pictures.

i say,

don't hang up, hang in.

you are not alone.

do not walk alone

into the eye of the lens

to be beaten, raped, tortured and mutilated.

do not walk alone

into the eye of the lens.

women walk together,

transform our tears

and our rage into action.

chant, scream, shout:

hey mister,

i ain't your pussycat, bitch or broad.

quit calling me chickie, cutie, fox or floozy.

i'm too old to be baby

or the little lady,

and i ain't Miss Dragon Lady

and Suzy Wong's been dead a long time. 